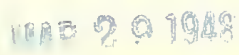

$10 \cdot 5-2 \times 3$

U. S. DEPAYTIENT OF COMMERCE

Letter

NATIORTL BUREAU OF STANDARDS

Mashington 25, D. C.

Circular

1.8891

( Superseding

IC858)

Revised to March 15, 1948

EURICATIONS RILATIMG TO BUILDING CODES AND CCNSTRUCIION PEACTICE

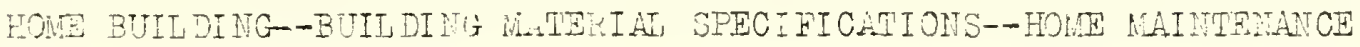

LEDERAL INFCHATION

Some of the publications ir tris list have appoared in tue reglatar series of the lational Burean of Standards. Where the price is stated, the mblication my be purchased from the Guperintendent of Decuments by remitting eitner coupons obtainable from him in sats of $20 \mathrm{fcr} \$ 1.00$ and good until used, or check or money ordər made pryable to tie Superintendent of Documents, Goverment Printing Office, Washiraton 25, D.C.

Publications listed as free may be obtained from the National Burzau of Standards.

Sərias letters with serial numbers are used to designate Bureau publications:

BH Building and Housing publication

BMS Building Matzrials and Structures publication

IC Letter Circular

M. Miscallanaous publication

Circular 024 and supplanents (a complete list of 3ureain's publications) is sold by the Superintendent of Iocuments for 1.30. Anrouncement of new Burəau publications is made each month in tne Technical Ners Bulletin, obtainable by subscription, from the Superintendent of Documents, at 1.00 a year in tine United states, Canada, Cuba, Mexico, Nevfoundland, and Republic of Pandina, other countries at $\$ 1.35$. 


\section{BUISDING CODES}

Iitle

Prepiraticr and revision of building codes (1939)
Series Price

BMS19 $15 \%$

Fertinent information for tine use of those chargad with

tho responsibility of preparing or revising biliding coises.

Builaing code requirements for now dwelling construction (1947)

Hecomenied standards for the erection of single- and twofamily houses and muliple dwellings of linited height.

Recominenzed minimum requirements for plumbing (1932)

BNSIOT 206

Faccmmendod cc de requiraments for plumbing installations in all types of buildings.

American standara building code requirements for masonry (1944)

i. 74

156

A complete' set of mirimum recuivements for masery constructicn c ther than reinforced.

Fire-resistance classifications of building corstructior (1942)

BNS92

$30 \notin$

Fire-resistance ratiuss and classifications of building construction and roofing raterials.

American standard building code requirements for minimum

design loads in buildirgs and other structurss (1945)

Pequirements relating to des.., live, wind, and earthauake 10313.

Design and construction of building exits (1935)

MI 51

$10 \mathrm{c}$

Observations of axit flow and recomrended building code reqiirements for exits.

List of published material ralating to building regulation(1947) IC847 Free

List of publications on buil ing and plumbing regriaticns

issued by the Iaticnal Bursau of Standards and the Amor-

ican Strndaris Associntion. 
Building materials and structures reports (1ist) (1947)

IC800 Free

Numerical Iist of Building Materials and Structures reports covering tests made at the National Bureau of Stindards of structural and other properties of building constructions, materials, and equipment.

Building materials and structures reports subject list

S

Free

Building Materials and Structures reports listed by sub jects.

Care and repair of the house (1931)

BiI5 20e

A book wrich points out the common defects and failures likely to occur in a house and which gives in handy form explicit directions for repair. work and maintenance necessary to kəep a house in good condition.

Leaflet describing BHI 5

BHI $5(1 \mathrm{ft})$ Frae

A brief description of the contents of BHI5, with an order blank.

Home heating problems: Iist of publications and articles(1948)

I. 889 Free

List of publicaticns and articles on home heating problems issued by the National Buraan of Standards, other Federal agencies, and National trade associations for home omners, home builders, and others interested in materials, equipment, and practices for installing and maintaining heating equipment.

House plan services (Iist of agencies) (1947)

LC866 Free

List of sources from which house plan bocklets, stock plans for houses, floor plans, or suggestions for small house design may be obtained.

List of published material relating to home building and maintenance (1948)

List of publications (intended to be of assistance to home owners, home builders, and others interested in materials, equipment, and practices employed in the construction, maintenance, and modernization of houses and other buildings) issued by the Federal government, National trade associations, and other organizations.

LC885 Free 
Title

Standards and specifications for building and construction materials, fixtures, supplias, and equipment (list) (1947)

List of Commercial Standards, Simplified Practice Recommendations, Federal Specifications, and publications on Building Codes, Construction Practices, and Home Maintenance with relation to building and construction materials, fixtures, sipplies, and equipment.

Suggestions for possible repairs and improvements in the house and its equipment (check list) (1931)

Iist of items to be cnecked for possible repairs in making periodic inspections of a house.

Tecinical information on building materials (list) (1947)

List of digests presenting in brief form essential facts developed through research work at the National Bureau of standards on the properties and uses of building materials.

\section{MISCALIANEOUS LISTS OF PIBI ICATIONS}

Iist of publications of interest to the general public. (1947)

$\operatorname{IC} 849$ Free

List of publications of the National Bureau of Standards and other Federal agencies coveing a wide range of information consicered to be of general interest.

Fublications of interest to suburbanites and home-builders (1947)
Series Price

LC860 Free

Ck-Sug Free

Price list of publications of interest to home o"mers and builders currently available from the U. S. Government Printing office. 